\title{
Petroclival Meningioma
}

National Cancer Institute

\section{Source}

National Cancer Institute. Petroclival Meningioma. NCI Thesaurus. Code C5278.

A meningioma that affects the petroclival region. 